\title{
SOSIAL MEDIA DAN PRESTASI BELAJAR: STUDI HUBUNGAN PENGGUNAAN FACEBOOK TERHADAP PRESTASI BELAJAR SISWA
}

\author{
Najamuddin'1, Habibi Ratu Perwira Negara², Deddy Ramdhani³ \\ \& Muhammad Nurman 4 \\ 1234Universitas Islam Negeri Mataram, NTB, Indonesia \\ 1najamuddin577@yahoo.co.id, 2habibiperwira@uinmataram.ac.id. \\ 3deddyramdhani@uinmataram.ac.id, ${ }^{4}$ mesharamdhita@gmail.com
}

\begin{abstract}
Abstrak
Penelitian ini bertujuan untuk mengetahui hubungan antara penggunaan jejaring sosial facebook terhadap prestasi belajar siswa. Subjek dalam penelitian ini adalah siswa MTs. Syamsul Huda Peresak yang berjumlah 34 orang. Penelitina ini merupakan penelitian korelasional. Pengumpulan data menggunakan angket tentang penggunaan jejaring sosial facebook dan dokumentasi hasil prestasi belajar siswa. Analisis menggunakan korelasi product moment. Hasil analisis data diperoleh bahwa nilai sig. $=0.775>0.05=\alpha$, sehingga disimpulkan bahwa tidak terdapat hubungan yang signifikat antara penggunaan jejaring sosial facebook terhadap prestasi belajar siswa.
\end{abstract}

Kata kunci: Pendidikan, Integrasi Teknologi Digital, Jejaring Sosial.

\begin{abstract}
The purpose of this research was to find out the relationship between using the facebook as social networking toward student achievement. The subjects in this study were students of MTs Syamsul Huda Peresak with total 34 students. This research is a correlational research. The data collection uses a questionnaire about the user of social networking Facebook and the documentation results of student learning achievements. The analysis uses product moment correlation. The results of data analysis show that the sig value. $=0.775>0.05=\alpha$, so it can be concluded that there is no significant relationship between using of Facebook as social networks to student learning achievements.
\end{abstract} Key words: Education, Digital Technology Integration, Social Media 
Najamuddin, N., Negara, H., Ramdhani, D., \& Nurman, M. (2019). SOSIAL MEDIA DAN PRESTASI BELAJAR: STUDI HUBUNGAN PENGGUNAAN FACEBOOK TERHADAP PRESTASI BELAJAR SISWA. Jurnal Tatsqif, 17(1), 70-86. https://doi.org/10.20414/itq.v17i1.296

\section{PENDAHULUAN}

Indonesia sebagai negara berkembang dengan wilayah kedaulatan yang sangat luas tentu saja membutuhkan lebih banyak sumber daya manusia yang unggul dan mampu bersaing baik dalam skala nasional maupun skala internasional. Untuk meningkatkan kualitas dan kuantitas sumber daya manusia Indonesia, pemerintah memiliki rencana strategis dalam bidang pendidikan. Untuk mendukung hal tersebut maka keberhasilan pendidikan tidak lepas dari berhasilnya proses belajar siswa. Suatu proses belajar dikatakan berhasil apabila didukung dengan motivasi siswa yang tinggi untuk belajar (Sardiman, 2006). Sehingga motivasi kegiatan belajar sangat mendukung keberhasilan dalam dunia pendidikan dalam bentuk prestasi.

Definisi prestasi belajar adalah penguasaan pengetahuan atau keterampilan yang dikembangkan melalui mata pelajaran, lazimnya ditujukan dengan nilai tes atau angka nilai yang diberikan oleh guru (Kamus Besar Bahasa Indonesia 2007) yang akan di peroleh selama menempuh semua proses pendidikan di sekolah selama satu semester. Proses belajar mengajar tersebut dapat terlaksana jika faktor-faktor yang mendukung prestasi belajar diperhatikan dengan baik. Faktor yang mempengaruhi prestasi belajar ada 2 yaitu Faktor internal yang berasal dari diri sendiri dan faktor eksternal yang berasal dari luar individu. Faktor internal adalah faktor jasmaniah, faktor psikologis dan faktor kelelahan. Sedangkan faktor eksternal adalah keadaan keluarga, keadaan sekolah, serta faktor lingkungan masyarakat (Slameto, 2003). Jika faktor-faktor tersebut berada dalam kondisi yang baik, maka akan sangat mendukung prestasi belajar siswa. Keberhasilan proses belajar mengajar yang baik dapat dilihat melalui hasil evaluasi siswa yang diterjemahkan dalam nilai rapor.

Prestasi belajar juga saat ini tidak terlepas dari perkembangan teknologi seperti internet, yang menghubungkan jaringan komputer satu dengan komputer lainnya. Media internet ini menjadi media yang tercepat dan mengalami inovasi sesuai dengan kebutuhan masyarakat. Artinya internet 
Najamuddin, N., Negara, H., Ramdhani, D., \& Nurman, M. (2019). SOSIAL MEDIA DAN PRESTASI BELAJAR: STUDI HUBUNGAN PENGGUNAAN FACEBOOK TERHADAP PRESTASI BELAJAR SISWA. Jurnal Tatsqif, 17(1), 70-86. https://doi.org/10.20414/itq.v17i1.296

bisa dikatakan sebagai media komunikasi massa (Onong, 2011). Sehingga internet mempunyai banyak pengaruh atau dampak terhadap dinamika kehidupan manusia dari segala bidang terutama dalam bidang pendidikan.

Pemakaian internet saat ini sangatlah mudah dan dapat dijangkau siapapun, di manapun, dan kapanpun. Contohnya, sekarang ini hampir semua alat komunikasi seperti handphone pun sudah memiliki aplikasi yang memudahkan penggunanya untuk menjelajah internet. Media sosial merupakan sarana percakapan yang terjadi di internet dan ditopang oleh alat berupa aplikasi atau software. Tidak seperti komunikasi di internet pada masa sebelumnya yang cenderung searah, komunikasi di social media kini bersifat interaktif, terbuka dan memungkinkan setiap orang untuk ikut berpartisipasi didalamnya. Pelaku utama yang meramaikan pergerakan tersebut sebagian besar didominasi oleh usia remaja, khususnya mereka para peserta didik, baik pelajar atau mahasiswa (Nasrullah, 2015). Hal ini wajar, sebab jika melihat latar belakang situs sosial media terbesar di Indonesia yaitu Facebook.

Facebook adalah salah satu media sosial yang berguna untuk mencari teman lama yang diaplikasikan dengan cara mengirim foto, video, bermain games, berdiskusi, dan masih banyak lagi. Media sosial ini didirikan pertama kali oleh Mark Zuckerberg bersama teman sekamarnya dan sesama mahasiswa Universitas Harvard, yaitu Eduardo, Saverin, Andrew Mc Collum, Dustin Moskovits dan Chris Hughes.

Bahkan kemajuan teknologi tersebut menyebabkan munculnya berbagai macam situs media sosial, seperti friendster, facebook, twitter, email, youtube, dan lain-lain. Sedangkan yang paling viral saat ini adalah media social facebook yang tentunya bukan merupakan hal yang asing bagi sebagian besar masyarakat Indonesia. Hal ini terbukti pengguna facebook sudah menyentuh semua kalangan, penggunaan facebook terbesar berasal dari kalangan pelajar/siswa sekolah. Banyaknya siswa yang memiliki akun dan menggemari facebook dapat dimanfaatkan dalam penggunaan facebook sebagai sarana meningkatkan motivasi dan prestasi belajar biologi siswa (Hanafi, 2006). 
Najamuddin, N., Negara, H., Ramdhani, D., \& Nurman, M. (2019). SOSIAL MEDIA DAN PRESTASI BELAJAR: STUDI HUBUNGAN PENGGUNAAN FACEBOOK TERHADAP PRESTASI BELAJAR SISWA. Jurnal Tatsqif, 17(1), 70-86. https://doi.org/10.20414/itq.v17i1.296

Sehingga dapat menciptakan kondisi belajar yang menarik dan diminati oleh siswa, serta memudahkan guru dalam proses pembelajaran, Hal ini didukung kemudahan-kemudahan yang ditawarkan oleh facebook yakni, penyampaian materi dapat digunakan cara share link/photo/video dan membuat resume pokok bahasan materi dengan fitur note atau docs pada group.

Teknologi informasi dan komunikasi seperti facebook pada era globalisasi seperti saat ini telah mengalami perkembangan yang sangat pesat dan berpengaruh terhadap tatanan kehidupan masyarakat di dunia, baik sosial budaya maupun sosial psikologis (Hamzah \& Lina, (2010). Perkembangan penggunaan multimedia dalam menyebarkan informasi dan komunikasi berpengaruh terhadap tatanan kehidupan bermasyarakat di dunia, baik sosial budaya maupun social psikologis. Sehingga penyebaran informasi dari waktu ke waktu sudah menembus segala penjuru dunia, hal tersebut mengakibatkan wawasan masyarakat terhadap peristiwa dunia makin terbuka dan berpengaruh terhadap pergeseran nilai dan norma yang berlaku baik secara langsung maupun tidak langsung terhadap suasana tersebut. Keadaan seperti ini hendaknya menjadi perhatian para praktisi penyedia konten terutama bagi mereka yang memiliki perhatian dan kemampuan lebih di bidang moral, untuk menyajikan produk-produk teknologi yang siap di serap dalam aplikasi yang bernuansa keagamaan sehingga bisa meminimalisir fitur digital yang miskin akan nilai-nilai moral (Feranita, 2017).

Kelebihan dan juga kekurangan dimiliki oleh media sosial ini. Adapun kelebihannya adalah bukan hanya menambah atau memperbanyak teman tetapi juga mempererat hubungan persahabatan, pertemanan, kekeluargaan, bahkan akhir-akhir terdapat tren baru yaitu online shop yang semakin memanjakan pengguna facebook dengan dapat berbelanja hanya dengan menggunakan facebook. Sedangkan kekurangannya adalah banyak orang yang menyalahgunakan facebook sebagai alat untuk menipu orang dan juga beberapa tindak kejahatan atau kriminal seperti yang sering diberitakan di televisi tentang prostitusi, pemerkosaan, dan penculikan yang berawal dari 
Najamuddin, N., Negara, H., Ramdhani, D., \& Nurman, M. (2019). SOSIAL MEDIA DAN PRESTASI BELAJAR: STUDI HUBUNGAN PENGGUNAAN FACEBOOK TERHADAP PRESTASI BELAJAR SISWA. Jurnal Tatsqif, 17(1), 70-86. https://doi.org/10.20414/itq.v17i1.296

facebook (Hasan \& Fuad, 2013). Tidak hanya kehidupan umum yang terkena dampak dari facebook, namun pengaruhnya mulai dirasakan dalam dunia pendidikan. Dampak terburuknya adalah menurunnya hasil belajar siswa di sekolah.

Siswa dalam usia remaja, dengan facebook mereka menjadi ekspresif dengan bebas membuat status upload foto dan berbagai catatan. Siswa juga tidak enggan wall to wall dengan gurunya, padahal dilapangan mereka enggan komunikasi. Guru yang cerdas adalah guru yang dapat memanfaatkan media termasuk facebook, sehingga guru bisa jadi pengarah sekaligus pengawas siswanya di luar sekolah. Pendidik bisa menggunakan fitur foto tagging untuk mengumpulkan siswanya dengan penjelasan sebuah foto dan meminta siswanya untuk berkomentar pada foto tersebut. Facebook dapat menjadi media pembelajaran yang baik untuk para penggunanya terutama pelajar. Tetapi faktanya masih banyak para pelajar menggunakan facebook untuk halhal yang kurang baik, seperti saling ejek dengan teman, berbagi foto yang tidak wajar ataupun mengumbar gosip yang tidak jelas dan menimbulkan kejahatan.

Di kalangan remaja, facebook sangat diminati, terlihat dari antusias mereka yang sangat sering menggunakan jaringan sosial ini untuk berkomunikasi dengan teman-teman mereka. Bahkan terkadang ada yang sampai lupa waktu jika telah bermain dengan jaringan sosial yang satu ini. Hal ini tentu dapat berdampak terhadap remaja tersebut. Waktu yang seharusnya digunakan untuk belajar, malah digunakan untuk bermain di dunia maya yang dapat mengakibatkan terhadap penurunan prestasi belajar mereka (Arifin, 2009).

MTs Syamsul Huda Peresak adalah salah satu madrasah swasta yang terletak di desa Sepakek Kecamatan Pringgarata Kabupaten Lombok Tengah. Berdasarkan hasil survey lapangan awal di madrasah ini, ada beberapa informasi yang diperoleh yaitu jumlah murid yaitu 84 siswa dan tenaga pendidik dan tenaga kependidikan 21 orang. Hasil wawancara dengan salah seorang guru mata pelajaran TIK (Teknologi Informasi Komputer) 
Najamuddin, N., Negara, H., Ramdhani, D., \& Nurman, M. (2019). SOSIAL MEDIA DAN PRESTASI BELAJAR: STUDI HUBUNGAN PENGGUNAAN FACEBOOK TERHADAP PRESTASI BELAJAR SISWA. Jurnal Tatsqif, 17(1), 70-86. https://doi.org/10.20414/itq.v17i1.296

menjelaskan bahwa hampir 70 \% siswa di madrasah ini memiliki HP (Hand Phone) dan sudah mengenal internet terutama facebook.

MTs Syamsul Huda Peresak mempunyai misi menghasilkan tamatan yang ber-IMTAQ dan ber-IPTEK sehingga mampu menghadapi era globalisasi, mengoptimalkan sumber daya manusia dalam era persaingan bebas. Salah satu cara untuk mewujudkan cita-cita tersebut, madrasah mencoba menggunakan teknologi informasi sebagai sumber belajar dan fasilitas belajar. Namun di saat perkembangan teknologi informasi begitu cepat, madrasah melarang siswanya untuk membawa handphone di lingkungan madrasah dengan alasan agar tidak menggangu siswa dalam proses belajar mengajar. Namun faktanya, berdasarkan wawancara langsung kepada beberapa siswa, diketahui bahwa masih terdapat beberapa siswa yang membawa handphone, salah satunya digunakan untuk mengakses situs jejaring sosial facebook meskipun tanpa sepengetahuan guru. Pada saat jam pelajaran kosong atau istirahat dimanfaatkan siswa untuk mengakses facebooknya.

Aktivita para penggunana facebooknya telah dimulai sejak bangun tidur, ketika sampai di kantor atai sekolah, sambil bekerja atau belajar bahkan hingga pulang dari kantor atau sekolah. Dapat dikatakan bahwa aktivitas sehari-hari kini tidak bias lepas dari facebooknya. Kebiasaan ini menjadi suatu rutinatas pada para pengguna facebooknya begitu pula pada siswa MTs Syamsul Huda Peresak.

Fakta ini seolah memperkuat pendapat Schouwenburg (dalam Ferrari, 1995) yang menagatajan bahwa individu memiliki kecenderungan unutk melakukan aktivitas lain yang lebih menyenangkan dari pada melakukan tugas yang harus dikerjakan. Sedangkan Onwuegbuzie (2000) menilai bahwa individu akan memilih unutk melarikan diri dari masalah ke internet. Hal inilah yang kemudian dapat memunculkan penundaan dalam menyelesaikan tugas yang berimbas pada prestasi belajar.

Kejenuhan dalam belajar, suasana kelas, lingkungan sekolah maupun metode pengajaran guru yang dirasa membosankan, menjadikan facebook 
Najamuddin, N., Negara, H., Ramdhani, D., \& Nurman, M. (2019). SOSIAL MEDIA DAN PRESTASI BELAJAR: STUDI HUBUNGAN PENGGUNAAN FACEBOOK TERHADAP PRESTASI BELAJAR SISWA. Jurnal Tatsqif, 17(1), 70-86. https://doi.org/10.20414/itq.v17i1.296

sebagai pilihan dalam mengurangi kejenuhan siswa MTs Syamsul Huda Peresak. Kebiasaan ini dapat memiliki dampak positif maupun negatif terhadap prestasi belajar. Dampak positif berupa penggunaan facebook untuk mendukung kegiatan belajar siswa, seperti membuat diskusi lewat group, memperoleh informasi yang dapat memotivasi belajar, dan sebagainya. Sisi negatif yang dapat terjadi apabila pengguna facebook lalai dan lupa waktu dalam mengakses, mengklik, informasi-informasi yang tidak bermanfaat dan mendukung prestasi belajar. Dampak negatif ini selain menurunnya prestasi belajar, berakibat pula pada interaksi social secara langsung antar siswa, dimana siswa akan sibuk hanya berinteraksi pada sejumlah komunita sosial di dunia maya yang belum tentu akan memiliki dampak yang sama saat berinteraksi secara langsung.

Berdasarkan uraian yang telah dipaparkan diatas, maka pemanfaatan internet terutama facebook bagi kalangan pelajar akan ada konsekuensinya. Salah satunya yaitu terhadap prestasi belajarnya. Baik dan buruknya akan diperoleh dari apa yang dilakukan siswa tersebut. Oleh karena itu, dalam penelitian ini rumusan masalah yang diangkat adalah apakah terdapat hubungan antara penggunaan jejaring sosial facebook terhadap prestasi belajar siswa MTs. Syamsul Huda Peresak, Desa Sepakek, Kecamatan Pringgarata, Kabupaten Lombok Tengah?.

\section{LANDASAN TEORI}

Facebook merupakan jejaring sosial (social network) yang bisa dimanfaatkan oleh para pengguna untuk saling mengenal dan berkomunikasi dalam berbagai keperluan dan juga bersifat rekreasi. Facebook adalah situs website jejaring social yang diluncurkan pada 4 Februari 2004 dan didirikan oleh Mark Zuckerberg, seorang lulusan Harvard dan mantan murid Ardsley High School (Mardiana \& Rizky, 2009). Keanggotaannya pada awalnya dibatasi untuk siswa dari Harvard College. Dalam dua bulan selanjutnya, keanggotaannya diperluas ke sekolah lain di wilayah Boston (Boston College, 
Najamuddin, N., Negara, H., Ramdhani, D., \& Nurman, M. (2019). SOSIAL MEDIA DAN PRESTASI BELAJAR: STUDI HUBUNGAN PENGGUNAAN FACEBOOK TERHADAP PRESTASI BELAJAR SISWA. Jurnal Tatsqif, 17(1), 70-86. https://doi.org/10.20414/itq.v17i1.296

Boston University, MIT, Tufts), Rochester, Stanford, NYU, Northwestern, dan semua sekolah yang termasuk dalam Ivy League. Banyak perguruan tinggi lain yang selanjutnya ditambahkan berturut-turut dalam kurun waktu satu tahun setelah peluncurannya. Akhirnya, orang-orang yang memiliki alamat surat email suatu universitas (seperti: .edu, .ac, .uk, dll) dari seluruh dunia dapat juga bergabung dengan situs jejaring social ini.

Selanjutnya dikembangkan pula jaringan untuk sekolah-sekolah tingkat atas dan beberapa perusahaan besar. Sejak 11 September 2006, orang dengan alamat surat email apapun dapat mendaftar di Facebook. Pengguna dapat memilih untuk bergabung dengan satu atau lebih jaringan yang tersedia, seperti berdasarkan sekolah, tempat kerja, atau wilayah geografis. Hingga Juli 2007, situs ini memiliki jumlah pengguna terdaftar paling besar di antara situs-situs yang berfokus pada sekolah dengan lebih dari 34 juta anggota aktif yang dimilikinya dari seluruh dunia. Dari September 2006 hingga September 2007, peringkatnya naik dari posisi ke-60 ke posisi ke-7 situs paling banyak dikunjungi, dan merupakan situs nomor satu untuk foto di Amerika Serikat, mengungguli situs publik lain seperti Flickr, dengan 8,5 juta foto dimuat setiap harinya.

Menurut (Adrianto M.Wijaya Ssi, MT, 2010) terdapat dampak negatif dan positif mengakses Facebook bagi pelajar yaitu: Dampak negatif Facebook bagi pelajar, Banyaknya kasus kriminalitas baik penipuan atau sebagainya , Menyita waktu belajar bagi pelajar, Mengobsesi waktu para pelajar untuk selalu mengakses facebook, Para pelajar tidak peduli dengan daerah sekitarnya, Menghamburkan uang terlebih lagi jika mengakses facebook di warnet, Mengganggu kesehatan mata karena terus duduk di depan computer, Data pribadi yang menyebar luas , Timbulnya rasa malas, baik mandi, makan ataupun sebagainya.

Adapun Dampak positif Facebook bagi pelajar: Mendapatkan mendapatkan teman yang banyak, Mempermudah berkomunikasi dengan kerabat di tempat yang jauh, Mendapatkan info-info tertemtu dengan mudah, 
Najamuddin, N., Negara, H., Ramdhani, D., \& Nurman, M. (2019). SOSIAL MEDIA DAN PRESTASI BELAJAR: STUDI HUBUNGAN PENGGUNAAN FACEBOOK TERHADAP PRESTASI BELAJAR SISWA. Jurnal Tatsqif, 17(1), 70-86. https://doi.org/10.20414/itq.v17i1.296

Menjadi sarana untuk berdiskusi ilmiah bagi para pelajar, Mendapatkan tali persaudaraan, Sebagai tempat diskusi, Sebagai sarana untuk promosi.

Semua siswa yang sedang menjalani proses belajar menginginkan dirinya dapat berprestasi. Namun dalam meraih prestasi belajar, terdapat beberapa faktor yang mempengaruhi. (Menurut Slameto 2003), faktor yang mempengaruhi prestasi belajar adalah:

1. Faktor internal adalah faktor yang terdapat dari dalam diri siswa.

a. Faktor jasmaniah, yang meliputi: kesehatan dan cacat tubuh

b. Faktor psikologis, yang meliput: intelengensi, perhatian, minat, bakat, motif, kematangan dan kesiapan.

c. Faktor Kelelahan, yang meliputi: kelelahan jasmani dan rohani.

2. Faktor eksternal adalah faktor yang berasal dari luar individu.

a. Keadaan keluarga yang meliputi: cara orang tua dalam mendidik, relasi antar anggota keluarga, suasana rumah, keadaan ekonomi keluarga, pengertian orang tua, serta latarbelakang kebudayaan masing-masing keluarga.

b. Keadaan sekolah meliputi: metode guru mengajar, relasi gurudengan siswa, relasi siswa dengan siswa, disiplin sekolah, alatpelajaran, waktu sekolah, keadaan gedung, metode belajar dantugas rumah.

c. Lingkungan masyarakat disekitar tempat tinggal, yang meliputikegiatan siswa dalam masyarakat, mass media, teman bergaul, bentuk kehidupan masyarakat.

\section{METODE PENELITIAN}

Penelitian ini merupakan penelitian korelasional. Sampel penelitian adalah siswa MTs. Syamsul Huda Peresak semester genap tahun ajaran 2017/2018. Teknik pengumpulan data menggunakan angket tentang penggunaan jejaring social facebook yang terdiri dari 52 butir pertanyaan dan dokumentasi hasil prestasi belajar siswa. Keabsahan data atau kevalidan data dilakukan dengan uji validitas dan reabilitas angket. Analisis data dilakukan 
dengan korelasi product moment dengan terlebih dahulu dilakukan uji asumsi awal berupa uji normalitas dan uji linearitas.

\section{HASIL DAN PEMBAHASAN}

\section{A. Hasil Penelitian}

\section{Penggunaan Jejaring Sosial Facebook}

Penggunaan jejaring sosial facebook diungkap melalui angket yang telah dinyatakan valid dan realiabel. Angket yang digunakan merupakan angket tertutup yang terdiri dari 52 butir yang disebar kepada 34 siswa MTs. Syamsul Huda Peresak. Berikut adalah hasil respon siswa terhadap pemberian angket penggunaan jejaring sosial facebook yang telah dilakukan.

\section{Penggunaan Jejaring Sosial Facebook}

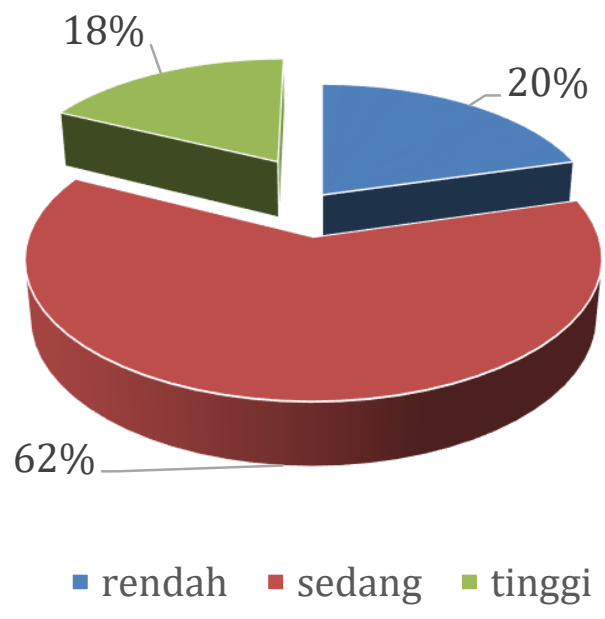

Gambar 1. Respon Siswa dalam menggunakan Jejaring Sosial Facebook

Berdasarkan diagram di atas, bahwa siswa MTs. Syamsul Huda Peresak dalam penggunaan jejaring sosial facebook tergolong sedang sebesar $62 \%$ atau sebanyak 21 siswa. Sebesar $18 \%$ atau sebanyak 6 siswa tergolong tinggi dalam penggunaan jejaring sosial facebook dan sebesar $20 \%$ atau sebanyak 7 siswa tergolong rendah dalam penggunaan jejaring sosial facebook.

\section{Prestasi Belajar}


Hasil belajar siswa MTs Syamsul Huda Peresak yang digunakan adalah hasil belajar siswa pada semester genap tahun ajaran 2017/2018.

Gambar 2. Prestasi Belajar Siswa MTs Syamsul Huda Peresak

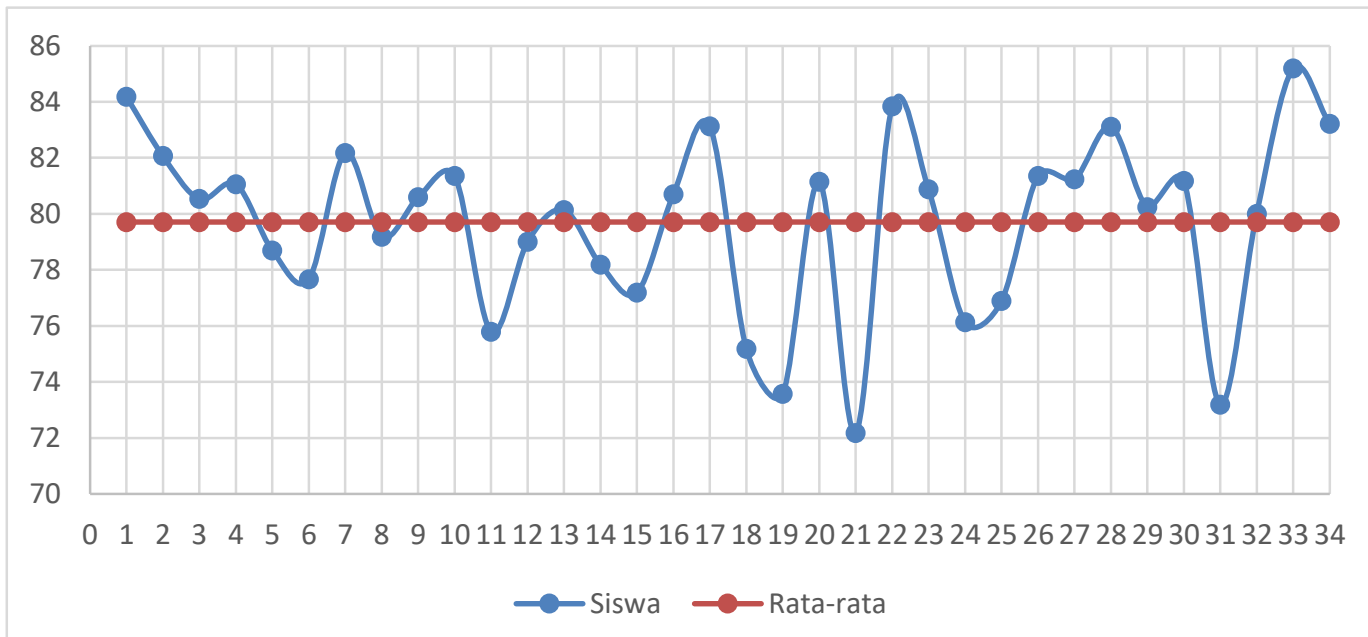

Berdasarkan Gambar 2 di atas, rata-rata prestasi belajar siswa MTs Syamsul Huda Peresak semester genap tahun ajaran 2017/2018 adalah 79.71.

\section{Hasil Uji Hoptesis}

Sebelum melakukan uji hipotesis, terlebih dahulu dilakukan uji asumsi untuk melihat apakah data yang diperoleh memenuhi syarat untuk dianalisis. Uji asumsi dalam penelitian ini meliputi uj normalitas dan uji Linearitas. Hasil uji normalitas disajikan pada Tabel 1 sebagai berikut.

Tabel 1. Uji Normalitas Data

\begin{tabular}{|l|r|r|r|}
\hline \multirow{2}{*}{} & \multicolumn{3}{|c|}{ Shapiro-Wilk } \\
\cline { 2 - 4 } & Statistic & \multicolumn{1}{c|}{ df } & \multicolumn{1}{c|}{ Sig. } \\
\hline Penggunaan_Facebook & .977 & 34 & .665 \\
Prestasi_Belajar & .952 & 34 & .139 \\
\hline
\end{tabular}

Berdasarkan Tabel 1 di atas, variabel penggunaan facebook dan presatasi belajar mempunyai nilai signifikan (Sig.) lebih besar dari $\alpha=0.05$. Hal ini menunjukkan bahwa data penggunaan facebook dan prestasi belajar berdistribusi normal.

Selanjutnya Uji linearitas yang digunakan untuk menguji apakah hubungan antara variabel independent dan dependent mempunyai hubungan yang linear atau tidak. Hasil uji linearitas disajikan pada Tabel 2 sebagai 
berikut.

Tabel 2. Uji Linearitas

\begin{tabular}{|c|c|c|c|}
\hline & & $F$ & Sig. \\
\hline $\begin{array}{ll}\text { Prestasi_Belajar * } & \text { Between Groups } \\
\text { Penggunaan_Facebook } & \end{array}$ & $\begin{array}{l}\text { (Combined) } \\
\text { Linearity } \\
\text { Deviation from Linearity }\end{array}$ & $\begin{array}{l}.916 \\
.081 \\
.958 \\
\end{array}$ & $\begin{array}{l}.586 \\
.781 \\
.550\end{array}$ \\
\hline
\end{tabular}

Berdasarkan Tabel 2 di atas, pada baris Deviation from Linearity diperoleh nilai sig. $=0.550>0.05=\alpha$. Sehingga hubungan antara prestasi belajar dan penggunaan facebook adalah linear. Setelah uji asumsi terpenuhi, selanjutnya dilakukan uji hipotesis menggunakan korelasi product moment. Hasil uji hipotesis disajikan pada Tabel 3 sebagai berikut.

Tabel 3. Uji Hipotesis

\begin{tabular}{|ll|r|r|}
\hline & & Penggunaan_Facebook & Prestasi_Belajar \\
\hline Penggunaan_Facebook & Pearson Correlation & 1 & -.051 \\
& Sig. (2-tailed) & & .775 \\
& $\mathrm{~N}$ & 34 & 34 \\
\hline Prestasi_Belajar & Pearson Correlation & -.051 & 1 \\
& Sig. (2-tailed) & .775 & \\
& $\mathrm{~N}$ & 34 & 34 \\
\hline
\end{tabular}

Berdasarkan Tabel 3 di atas, pada baris sig. (2-tailed) diperoleh nilai $0.775>0.05$. Hasil ini menunjukan bahwa tidak terdapat hubungan antara penggunaan jejaring sosial facebook terhadap prestasi belajar siswa.

\section{B. Pembahasan}

Social media atau media sosial merupakan sarana percakapan yang terjadi di internet dan ditopang oleh alat berupa aplikasi atau software. Tidak seperti komunikasi di internet pada masa sebelumnya yang cenderung searah, komunikasi di social media kini bersifat interaktif, terbuka dan memungkinkan setiap orang untuk ikut berpartisipasi didalamnya. Interaksi di Facebook bisa dua arah maupun bersama-sama, karena di media tersebut bisa menulis status kemudian dapat dikomentari banyak teman yang bergabung di Facebook tersebut. 
Pengguna atau pelaku utama yang meramaikan pergerakan internet lebih spesifiknya Facebook sebagian besar didominasi oleh usia remaja yang masih aktif sekolah maupun kuliah, khususnya mereka para peserta didik, baik pelajar atau mahasiswa. Hal ini wajar, sebab jika melihat latar belakang situs sosial media terbesar di Indonesia yaitu Facebook, memang pada awal berdirinya dikhususkan untuk menghubungkan jalinan pertemanan di kampus. Beberapa situs social media yang populer sekarang ini antara lain: Blog, Twitter, Facebook, Wikipedia, dan YouTube. Perkembangan social media dalam dua tahun terakhir hingga tahun 2012 telah menujukkan grafik peningkatan yang signifikan penggunaan media ini. Jika media tradisional menggunakan media cetak dan media broadcast, maka social media menggunakan internet. Blog dan jejaring sosial merupakan bentuk social media yang paling umum digunakan oleh masyarakat di seluruh dunia. Social media internet online ini dapat menghubungkan pertemanan antar kota, Negara, maupun semua Negara seluruh dunia dapat mengakses media internet khususnya Facebook.

Meskipun sejumlah penelitian menunjukkan bahwa Facebook dapat dimanfaatkan sebagai media belajar untuk meningkatkan hasil belajar (Meinawati \& Baron, 2019) dan mampu mempengaruhi aktiftas siswa (Elia, 2009; Ardana, 2009), hasil penelitian ini menunjukkan bahwa intensitas penggunaan facebook tidak memiliki hubungan yang signifikan terhadap prestasi belajar. Temuan ini diperkuat dengan uji hipotesis, dimana dipeorleh bahwa tidak terdapat hubungan yang signifikan antara intensitas penggunaan jejaring sosial facebook terhadap prestasi belajar pada siswa di MTs Syamsul Huda Peresak (sig = $0.775>0.05=\alpha$ ).

Temuan penelitian ini menegaskan bahwa intensitas penggunaan Facebook tidak menjamin meningkatnya prestasi belajar siswa, bahkan hal ini berpotensi berdampak buruk bagi siswa jika tidak digunakan dengan tepat guna dan tidak memperhatikan prinisp pengintegrasian 
teknologi digital dalam pendidikan (Putrawangsa \& Hasanah, 2018). Hal ini dikarenakan Facebook diyakini memeiliki sejumlah pengaruh negatif bagi penggunaanya. Greenfield (dalam Elia, 2009), misalnya, menunjukkan bagaimana facebook dapat mempengaruhi kebiasaan siswa, seperti penundaan menyelesaikan tugas, sehingga berdampak pada menurunnya prestasi belajar. Greenfield berpendapat bahwa facebook memiliki daya menghipnotis sehingga godaan daya tarinya masih terus berlangsung bahkan saat seseorang tidak sedang tidak terhubung dengan internet. Greenfield juga menemukan bahwa rasa intim yang berlebihan membuat seseorang sulit melepaskan diri dari facebook. Hasil yang serupa pula dikemukaan oleh Ardana (2009), yaitu penggunaan internet yang berlebihan seperti facebook mampu menurunkan perfomace seseorang.

Namun, meskipun hasil penelitian ini menunjukkan bahwa tidak ada hubungan antara Facebook dengan prestasi belajar, penelitian ini tidak menegaskan bahwa Facebook tidak dapat digunakan untuk meningkatkan prestasi belajar. Penggunaan Facebook dengan tepat guna dengan memperhatikan prinsip integrasi teknologi digital dalam pembelajaran akan dapat memberikan dampak positif bagi siswa (Putrawangsa \& Hasanah, 2018). Meinawati \& Baron (2019), misalnya, dapat mengintegrasikan jejaring sosial Facebook dengan tepat guna untuk meningkatkan kemampuan siswa dalam menulis teks berbahasa Inggris. Pada konteks yang serupa, Khusniyah \& Hakim (2019) juga menunjukkan bahwa pembelajaran berbasis daring dapat meningkatkan prestasi belajar siswa.

Hasil penelitian ini memberikan tantangan ke depan bagi pendidik dan peneliti pendidikan tentang bagaimana memanfaatkan teknologi digital yang berkembang saat ini, seperti Facebook, dengan tepat guna sebagai media belajar untuk meningkatkan prestasi belajar siswa. Hal ini dikarenakan, di era Industri 4.0 saat ini, dunia pendidikan tidak dapat terlepas dari pengaruh perkembangan teknologi digital (Harto, 2018). 
Oleh karena itu, ke depan diperlukan riset yang fokus pada pengembangan kegiatan pembelajaran yang mengintegrasi teknologi digital, seperti Facebook, untuk meningkatkan prestasi belajar siswa. Hal ini menjadi tantangan peneliti pendidikan di masa akan datang.

\section{KESIMPULAN}

Pengguna jejering sosial facebook meliputi seluruh aspek lapisan masyarakat, termasuk anak sekolahan. Penggunaan jejaring sosial facebook dapat berdampak positif maupun negatif terhadap tumbuh kembang maupun prestasi belajar siswa. Berdasarkan hasil analisis data disimpulkan bahwa tidak terdapat hubungan antara penggunaan jejaring sosial facebook terhadap prestasi belajar siswa.

Meskipun hasil penelitian ini menunjukkan bahwa tidak ada hubungan antara Facebook dengan prestasi belajar, penelitian ini tidak menegaskan bahwa Facebook tidak dapat digunakan untuk meningkatkan prestasi belajar. Penggunaan Facebook dengan tepat guna dengan memperhatikan prinsip integrasi teknologi digital dalam pembelajaran diyakini dapat memberikan dampak positif bagi siswa (Putrawangsa \& Hasanah, 2018; Meinawati \& Baron, 2019). Hal ini menjadi tantangan bagi pendidik dan peneliti pendidikan, yaitu bagaimana memanfaatkan teknologi digital yang berkembang saat ini, seperti Facebook, dengan tepat guna sebagai media belajar untuk meningkatkan prestasi belajar siswa. Dalam hal ini, diperlukan riset yang fokus pada pengembangan kegiatan pembelajaran yang mengintegrasi teknologi digital untuk meningkatkan prestasi belajar siswa.

\section{DAFTAR PUSTAKA}

Ardana, K.Y.M., \& Dita D.V. (2009). Mengungkap misteri facebook. Yogyakarta: Apel Media.

Arifin, Hasnul, (2009). Nongkrong Asyik di Internet dengan Facebook. Jakarta : Buku Kita. 
Najamuddin, N., Negara, H., Ramdhani, D., \& Nurman, M. (2019). SOSIAL MEDIA DAN PRESTASI BELAJAR: STUDI HUBUNGAN PENGGUNAAN FACEBOOK TERHADAP PRESTASI BELAJAR SISWA. Jurnal Tatsqif, 17(1), 70-86. https://doi.org/10.20414/itq.v17i1.296

Elia, H. (2009). Kecanduan berinternet dan prinsip-prinsip untuk menolong pecandu internet. Veritas: Jurnal Teologi dan Pelayanan, 10(2), 285-299. Feranita, (2017). Pengaruh Media Sosial Facebook Terhadap Hasil Belajar Akidah Akhlak di MA Syamsul Ulum Kota Sukabumi, Jawa Barat.

Ferrari, J.R., Johnson, J.L., \& McCown, W.G. (1995). Procrastination and task avoidance: Theory, research, and treatment. New York: Plenum Press.

Hamzah \& Lina, (2010). Teknologi Komunikasi \& Informasi Pembelajaran. Jakarta: Bumi Aksara.

Hanafi, M, (2006). Pengaruh Media Sosial facebook terhadap motivasi belajar mahasiswa Fisip Universitas Riau. Jurnal Jom Fisip.

Harto, K. (2018). TANTANGAN DOSEN PTKI DI ERA INDUSTRI 4.0. Jurnal Tatsqif, 16(1), 1-15. https://doi.org/10.20414/itq.v16i1.159

Hasan \& Fuad, (2013). Efektivitas Jejaring Sosial Facebook Sebagai Media Dakwah (Studi Terhadap Facebook Yusuf Mansur), Skripsi, Jurusan Komunikasi dan Penyiaran Islam Fakultas Dakwah, UIN Sunan Kalijaga Yogyakarta.

Khusniyah, N., \& Hakim, L. (2019). EFEKTIVITAS PEMBELAJARAN BERBASIS DARING: SEBUAH BUKTI PADA PEMBELAJARAN BAHASA INGGRIS. Jurnal Tatsqif, 17(1), 19-33. https://doi.org/10.20414/itq.v17i1.667

Mardiana Wati \& A.R. Rizky, (2009) Lima Jam Menjadi Terkenal Lewat Facebooke. Bandung: Yrama Widya.

Meinawati, E., \& Baron, R. (2019). MEDIA SOSIAL DAN PEMBELAJARAN: STUDI EFEKTIVITAS PENGGUNAAN FACEBOOK DALAM PEMBELAJARAN BAHASA INGGRIS. Jurnal Tatsqif, 17(1), 34-51. https://doi.org/10.20414/jtq.v17i1.679

Nasrullah, R, (2015). Media Sosial Remaja. Bandung: Rosdakarya.

Onong, U.E. (2011). Ilmu Komunikasi dan Praktek. Bandung : PT. Remaja Rosdakarya.

Onwuegbuizie, A.J., \& Qun G. Jiao. (2000), I'II go to the library later: The relationship between academic procrastination and library anxiety. 
College and Research Libraries. 61(1). Chicago: Association of College dan Research Libraries.

Putrawangsa, S., \& Hasanah, U. (2018). INTEGRASI TEKNOLOGI DIGITAL DALAM PEMBELAJARAN DI ERA INDUSTRI 4.0. Jurnal Tatsqif, 16(1), 4254. https://doi.org/10.20414/itq.v16i1.203

Sardiman, A. M, (2006). Interaksi dan Motivasi Belajar Mengajar, Jakarta : PT Raja Grafindo Persada.

Slameto, (2003). Belajar dan Faktor- faktor yang Mempengaruhinya. Jakarta: PT. Rineka Cipta. 